JURNAL KETAHANAN NASIONAL

Vol. 25, No. 1, April 2019, Hal 36-55

DOI:http://dx.doi.org/ 10.22146/jkn.41866

ISSN:0853-9340 (Print), ISSN:2527-9688 (Online)

Online sejak 28 Desember 2015 di :http://jurnal.ugm.ac.id/JKN

VOLUME 25

No. 1, April 2019

Halaman 36-55

\title{
Internalisasi Bela Negara Dalam Pembinaan Kegiatan Pemuda Purna Paskibraka Kabupaten Bandung Untuk Pembentukan Ketahanan Pribadi
}

\author{
Widodo Suryaningrat \\ Kantor Angkatan Udara \\ email: widodosurya81@gmail.com \\ Armaidy Armawi \\ Prodi Ketahanan Nasional Sps UGM \\ email: armaidy@ugm.ac.id \\ Djoko Soerjo \\ Fakultas Ilmu Budaya UGM \\ email: djoko@ugm.ac.id
}

\begin{abstract}
In this study, it discussed the development of youth in the Indonesian Alumni Paskibraka organization in planting the values of national defense and its implications for personal resilience. This research was conducted at the Purna Paskibraka Indonesia (PPI) organization in Bandung Regency. The purpose of this study were to knew and analyzed the formation of youth in the Full Paskibraka Indonesia in Bandung Regency in the cultivation of values of national defense during the education and training process, and to knew and analyzed the implications of internalizing the defense of the Bandung Regency in terms of personal resilience the paskibraka and alumni.

This research used descriptive qualitative research method, where the subject of the researchwas Purna Paskibraka Indonesia, Bandung Regency and the object of research was PPI youth in activities to maintained the values of state defense and its implications for personal resilience. Methods of data collection used the structured interviews, observation, literature studies, documentation studies, and online page search. Data analysis techniques in this study used data reduction, data presentation, and conclusion.

The results of the study showed that understanding the concept of state defense was a matter that must be understood and carried out by every citizen according to the guidance of the Act. PPI as a youth organization consisting of selected elements of civil society and special education, must took responsibility for the country's defense efforts in accordance with the capacity of their organization.Purna Paskibraka Indonesia (PPI) participating in the state defense activities in Bandung Regency was carried out through four models of activities which also produced pillars of commitment. From this participation, it provided an understanding of the values of the nation and state, which then gave awareness to the obligation to defended the country, and also stated its commitment to defended the country. The youth who became the Alumni Paskibraka Indonesia of Bandung Regency showed a strong sense of belonging to the nation and state of Indonesia, showing the pride of identity as an Indonesian nation, having good personal character and showing nationalism at a real level. Therefore, the internalization of state defense must be improved, so that personal resilience could be realized and helped to createdthe national resilience in Indonesia.
\end{abstract}

Keywords: Youth, Paskibraka, Defending Country, Character, Personal Resilience. 
Widodo Suryaningrat, Armaidy Armawi, Djoko Soerjo -- Internalisasi Bela Negara Dalam Pembinaan Kegiatan Pemuda Purna Paskibraka Kabupaten Bandung Untuk Pembentukan Ketahanan Pribadi

\begin{abstract}
ABSTRAK
Pada penelitian ini membahas tentang pembinaan pemuda dalam organisasi Purna Paskibraka Indonesia dalam penanaman nilai-nilai bela negara dan implikasinya terhadap ketahanan pribadi. Penelitian ini dilakukan pada organisasi Purna Paskibraka Indonesia Kabupaten Bandung. Tujuan penelitian ini adalahuntuk mengetahui dan menganalisis pembinaan pemuda Purna Paskibraka Indonesia Kabupaten Bandung dalam penanaman nilai-nilai bela negara selama mengikuti proses pendidikan dan latihan, danuntuk mengetahui dan menganalisis implikasi internalisasibela negara Purna Paskibraka Indonesia Kabupaten Bandung terhadap ketahanan pribadi para paskibraka dan alumninya.

Penelitian ini menggunakan metode penelitian kualitatif deskriptif, dimana subjek penelitian adalah Purna Paskibraka Indonesia Kabupaten Bandung dan objek penelitian adalah pemuda PPI dalam kegiatan untuk penanaman nilai-nilai bela negara dan implikasinya terhadap ketahanan pribadi. Metode pengumpulan data menggunakan wawancara secara terstruktur, observasi, studi pustaka, studi dokumentasi, dan penelusuran laman online. Teknik analisis data pada penelitian ini menggunakan reduksi data, penyajian data, dan penarikan kesimpulan.

Hasil penelitian menunjukkan bahwa pemahaman konsep bela negara menjadi suatu hal yang harus dipahami dan dilakukan oleh setiap warga negara sesuai tuntunan Undang-Undang. PPI selaku organisasi kepemudaaan yang terdiri atas unsur masyarakat sipil yang terpilih dan telah menempuh pendidikan secara khusus, harus turut bertanggung jawab atas usaha-usaha pembelaan negara sesuai kapasitas kemampuan organisasinya. Purna Paskibraka Indonesia berpartisipasi dalam kegiatan bela negara di Kabupaten Bandung dilakukan melalui empat model kegiatan yang juga menghasilkan pilar-pilar komitmen. Dari partisipasi tersebut memberikan pemahaman terhadap nilai-nilai berbangsa dan bernegara yang kemudian memberikan kesadaran terhadap kewajiban bela negara, serta menyatakan komitmennya terhadap bela negara. Pemuda yang menjadi Purna Paskibraka Indonesia Kabupaten Bandung menunjukkan adanya rasa memiliki yang kuat terhadap bangsa dan negara Indonesia, menunjukkan adanya kebanggaan akan jatidiri sebagai bangsa Indonesia, memiliki karakter pribadi yang baik dan menunjukkan nasionalisme dalam tataran nyata. Oleh karena itu internalisasi bela negara harus terus ditingkatkan, sehingga ketahanan pribadidapat terwujud dan membantu terciptanya ketahanan nasional di Indonesia.
\end{abstract}

Kata Kunci: Pemuda, Paskibraka, Bela Negara, Karakter, Ketahanan Pribadi.

\section{PENGANTAR}

Arus globalisasi yang melanda dunia telah membuat negara- negara pada masa kini seolah menjadi borderless yang akhirnya membawa Indonesia ke dalam interaksi antarbangsa yang semakin kompleks. Globalisasi yang terjadi saat ini dipengaruhi oleh poin HAM dan democracy telah menumbuhkan kesadaran secara merata untuk menyelamatkan manusia dari konflik di berbagai belahan duniaini semisal seperti peperangan dan ancaman baik fisik maupun non-fisik yang mengancam kehidupan umat manusia(Darmono, 2010:3).

Perubahan sedemikian cepat yang terjadi di negara Indonesia ini selama memasuki abad millenium sesungguhnya telah membawa penduduk negeri ini ke arah yang penuh dengan fragmentasi sekaligus kohesinya (Abdullah, 2010:77). Di satu pihak, dampak positif globalisasi membuat bangsa Indonesia menerima teknologi dan wawasan baru yang semakinup to date, sehingga informasi dan komunikasi dengan manusia di belahan dunia yang lain menjadi semakin cepat.

Di lain pihak, arus kencang globalisasi membawa pula dampak negatif dengan semakin tergerusnya nilai sosial dan kearifan lokal suatu bangsa. Pesatnya perkembangan teknologi yang akhirnya membawa bangsa Indonesia kepada tantangan yang baru. Bila ditinjau dari aspek Asta Gatra untuk posisi Indonesia, AGHT (Ancaman, Gangguan, Hambatan dan Tantangan) tentunya juga mengalami pergeseran makna. Potensi ancaman yang dihadapi Indonesia bukan lagi dalam bentuk serangan maupun agresi militer dari negara lain, tetapi lebih ke arah penaklukan dan peguasaan Asta Gatra. 
Pemuda masa kini terancam kurang maksimal dalam mengapresiasikan dan mengaktualisasikan diri sehingga mereka seolah terjebak pada lingkungan yang mengarah pada perilaku negatif. Degradasi ini bila dibiarkan berlarut maka dapat memperlemah para pemuda Indonesia baik secara fisik maupun mental, yang pada akhirnya dengan lingkup yang lebih luas dapat melemahkan ketahanan nasional Indonesia secara keseluruhan (Buasan, 2013:45). Bila dilihat pada Undang-Undang Nomor 3 Tahun 2002 tentang Sistem Pertahanan Negara disebutkan dalam Pasal 1 Ayat 2 bahwa :

"Sistem pertahanan negara adalah sistem pertahanan yang bersifat semesta yang melibatkan seluruh warga negara, wilayah dan sumber daya nasional lainnya, serta dipersiapkan secara dini oleh pemerintah dan diselenggarakan secara total, terpadu, terpadu, terarah dan berlanjut untuk menegakkan kedaulatan negara, keutuhan wilayah dan segenap bangsa dari segala ancaman".

Dari kutipan di atas, Tentara Nasional Indonesia merupakan komponen utama dalam sistem pertahanan negara, sedangkan warga negara berperan sebagai komponen cadangan dan pendukung. Terlihat bahwa persoalan pertahanan dan keamanan tidak hanya menjadi tanggung jawab militer saja, tetapi juga potensi sipil perlu dilibatkan sebagai wujud tanggung jawab seorang warga negara.

Suatu negara akan disegani bila memiliki keunggulan potensi militer dan sipil yang sinergis, walaupun di Indonesia belum tercipta kesadaran dari segenap diri warga negara bahwa usaha pembelaan negara merupakan salah satu kewajiban mereka. Penanaman kesadaran bela negara sejak usia muda sudah selayaknya segera dilakukan untuk semakin mencegah rendahnya semangat dan pengetahuan tentang hal tersebut. Pemuda harus secara proaktif ikut serta ambil bagian dalam kegiatan bela negara untuk mewujudkan ketahanan bangsa.

Garda terdepan bangsa yaitu pemuda sangat rentan mengalami tantangan moral, yang berdampak pada degradasi moralitas bangsa kelak. Pemuda sebagai pemegang estafet kepemimpinan bangsa merupakan aset berharga, dimana masa depan Indonesia berada di tangan para pemuda. Secara ideal, tentu diharapkan pemuda dapat menjadi solusi akan permasalahan bangsa ini untuk tampil sebagai pionir yang mampu memberikan solusi yang tanggap, tangguh dan trengginas untuk menjawab tantangan jaman yang semakin maju.

Fenomena merosotnya moral atau akhlak dari para tunas bangsa ini telah menjadi sorotan dari banyak pihak. Terjadinya krisis moral itu ketika ada suatu tabiat atau adab seseorang atau sekelompok orang yang menyimpang dari tuntunan ideal yang selazimnya dijadikan panutan, yaitu nilai agama dan budaya. (Armawi, 2006:63). Krisis sosio kultural ini seringkali bersifat massive yang terjadi dengan latar belakang dengan dinamika kehidupan sosial ekonomi di tengah arus dunia yang semakin modern dan menipisnya batas antar negara.

Wahana (2015:16) berpendapat bahwa saat ini seseorang memerlukan pengendali yang kuat agar mampu memilih dan memilah nilai-nilai yangbanyak sekali ditawarkan kepadanya. Oleh karena itu, agar seseorang tahan banting,maka bisa dilakukan dengan pendidikan, karena jalan terbaik dalam membangun pribadi seseorang, masyarakat, negara maupun dunia adalah melalui pendidikan. Fokus dari pendidikan sendiri 
ada tiga, yaitu membangun pengetahuan, membangun keterampilan (skill)dan membangun karakater. Berdasarkan ketiga elemen pendidikan tersebut, inti atau basis utamanya adalah karakter dan karakter adalah buah dari kebudayaan. Karakter sangat penting untuk dibangun karena secara langsung maupun tidak langsung akan berimplikasi pada ketahanan pribadi.

Dalam Permendagri Nomor 38 Tahun 2011 tentang Pembinaan Kesadaran Bela Negara menyebutkan bahwa Paskibraka merupakan salah satu kegiatan yang menumbuhkan kesadaran tentang bela negara. Pendidikan dan pembinaan mulai dari proses seleksi untuk calon anggota Paskibraka (Capaska), dilantik menjadi Paskibraka hingga menjadi alumni Purna Paskibraka, mereka akan mengalami internalisasi bela negara dan wawasan kebangsaan dalam rangkaian pembinaaanya.

Bergabung menjadi seorang anggota Paskibraka merupakan salah satu cara mewujudkan penanaman mengenai kesadaran bela negara di kalangan pemuda. Jiwa - jiwa dinamis dan idealis yang dimiliki para pemuda penerus dan harapan bangsa dapat tersalurkan secara positif, yaitu dengan menghadirkan aktualisasi dirinya dan segenap potensi yang dimilikinya di organisasi kepemudaan. Penanaman nilai-nilai bela negara dan wawasan kebangsaan yang berorientasi kepada pembangunan karakter pribadi yang tangguh setiap diri akan dimulai pada rangkaian kegiatan Paskibraka yang intensif.

Salah satu bentuk organisasi kepemudaan yang ada dan hadir di tengah-tengah masyarakat dan telah terdidik dengan sangat baik dan memiliki militansi yang tinggi yaitu Purna Paskibraka Indonesia (PPI). PPI sebagai wadah yang mengayomi para pemuda alumni pengibar bendera pusaka (Paskibraka) di tingkat kota dan kabupatenuntuk sarana komunikasi dan mengaktualisasikan dirinya pasca bertugas sebagai petugas pengibar bendera Merah Putih setiap tanggal 17 Agustus setiap tahunnya. Di bawah pembinaan Dinas Kepemudaan dan Olahraga, PPI ini menanamkan nilai-nilai luhur tentang patriotisme, nasionalisme, cinta tanah air, dan pemahaman bela negara. Keberadaan PPI yang terbentuk hampir di setiap wilayah kota dan kabupaten di Indonesia menjadikan organisasi ini menjadi perkumpulan yang menjunjung tinggi kedisiplinan dan doktrin nasionalisme yang membuat pemuda tumbuh semangat bela negara yang tinggi.

Dalam UU Nomor 40 Tahun 2009 tentang Kepemudaan disebutkan dalam Pasal 1 Ayat 1 bahwa yang disebut pemuda adalah warga negara Indonesia yang memasuki periode penting pertumbuhan dan perkembangan yang berusia 16 sampai 30 tahun. Pemuda merupakan aset penting dalam sebuah negara, terlebih bila melihat sejarah Indonesia, di mana kemerdekaan negara Indonesia pada 17 Agustus 1945 merupakan inisiator dari kaum muda pada waktu itu. Pemuda dengan semangatnya yang tinggi menawarkan kreativitas dan gagasan yang inovatif, hingga inilah yang membedakan pemuda dengan golongan masyarakat lain.

Masa kehidupan manusia yang paling optimal ketika usia muda karena masa itulah kematangan jasmani, perasaan dan akalnya, serta kepekaan yang tinggi terhadap lingkungan dimiliki pemuda (Setiawan, 2009:71). Dalam suatu negara, pemuda merupakan modal sosial atau agents of changedan pemegang kebijakan masa depan sebuah negara. Oleh karenanya sebagai kategori sosial, pemuda harus selalu bergerak melakukan kerja sosial 
dan perubahan, di samping mempersiapkan diri dengan perangkat intelektual (Setiawan, 2009:73).

Internalisasi merupakan suatu proses memasukkan nilai atau memasukkan sikap ideal yang sebelumnya dianggap berada di luar, agar tergabung dalam pemikiran seseorang dalam pemikiran, keterampilan dan sikap dan pandangan hidup seseorang (Djono, 2016). Internalisasi sebagai salah satu metode, prosedur, dan teknik dalam siklus manajemen pengetahuan yang digunakan para pendidik untuk memberikan kesempatan kepada anggota suatu kelompok, organisasi, instansi, perusahaan atau anak didik agar berbagi pengetahuan yang mereka miliki kepada anggota lainnya.

Merujuk pada Basrie (1998:5) bela negara adalah tekad, sikap, dan tindakan warga negara yang teratur, menyeluruh, terpadu dan berlanjut yang dilandasi oleh kecintaan pada tanah air, kesadaran berbangsa dan bernegara Indonesia, keyakinan akan kesaktian Pancasila sebagai ideologi negara, dan kerelaan untuk berkorban guna meniadakan setiap ancaman baik dari luar maupun dari dalam negeri yang membahayakan kemerdekaan dan kedaulatan negara, kesatuan dan persatuan bangsa, keutuhan wilayah dan yurisdiksi nasional, serta nilai-nilai Pancasila dan UUD 1945. Menurut pengertian yang lain, bela negara merupakan hak sekaligus kewajiban yang harus melekat pada seluruh warga negara seperti yang termaktub dalam pasal 30 UUD 1945. Pertahanan dan keamanan negara adalah salah satu fungsi pemerintahan untuk menghadapi dan meniadakan segala ancaman baik dari dalam maupun luar negeri, yang diselenggarakan melalui sistem pertahanan dan keamanan rakyat semesta sebagai suatu cara pandang yang menempatkan pertahanan dan keamanan negara sebagai tanggung jawab bersama seluruh warga negara dengan hak dan kewajiban yang dijamin oleh UUD 1945 (Perwita, 2006:5).

Masyarakat sipil selaku komponen pendukung dalam sistem pertahanan dan keamanan negara memiliki peranan yang penting. Masyarakat yang memiliki pengetahuan tantang wawasan nusantara maka akan menimbulkan kesadaran bela negara yang tinggi akan menjadi benteng pertahanan negara yang kokoh dalam menopang ketahanan nasional.

Bela negara pada umumnya dipersepsikan identik dengan pertahanan keamanan. Hal ini karena sejak awal berdirinya Negara Kesatuan Republik Indonesia, keikutsertaan warga negara dalam bela negara diwujudkan dalam kegiatan bidang pertahanan dan keamanan (Basrie, 1994). Melihat kepada fenomena saat ini, kondisi ketahanan bangsa Indonesia tidak terlepas dari faktor geopolitik yang dinamis akibat dari cepatnya arus globalisasi yang terjadi.

Undang-Undang Nomor 3 tahun 2002 tentang Pertahanan Negara pasal 9 disebutkan bahwa setiap warga negara berhak dan wajib ikut serta dalam upaya bela negarayang diwujudkan dalam penyelenggaraan pertahanan negara. Keikutsertaan ini diselenggarakan melalui pendidikan kewarganegaraan, pelatihan dasar kemiliteran secara wajib, pengabdian sebagai prajurit TNI secara sekarela atau wajib dan pengabdian sesuai dengan profesi.

Dalam Peraturan Menteri Pertahanan Nomor 32 Tahun 2016 tentang Pedoman Pembinaan Kesadaran Bela Negara telah dirumuskan indikator nilai bela negara yang merupakan indikator keluaran maupun indikator masukan pelaksanakan pembinaan kesadaran bela negara. Berikut nilai-nilai 
bela negara beserta indikator yang telah dirumuskan dalam Permenhan RI tersebut, yaitu (1). Cinta tanah air, (2). Kesadaran berbangsa dan bernegara, (3). Setia pada Pancasila sebagai ideologi negara, (4). Rela berkorban untuk bangsa dan negara, dan (5). Memiliki kemampuan awal bela negara (kesiapan fisik dan mental)

Dari tinjauan berdasarkan latar belakang di atas, fokus permasalahan penelitian inidirumuskan menjadi dua bagian besar yaitu dengan meneliti untuk mengetahui kegiatan dan partisipasi pemuda Purna Paskibraka Indonesia (PPI) Kabupaten Bandung dalam penanaman nilai-nilai bela negara, serta mengkaji implikasi pembinaan kegiatan pemuda PPI Kabupaten Bandung dalam penanaman nilai-nilai negara untuk mewujudkan ketahanan pribadi. Personil yang mengawaki organisasi PPI ini menjadi subyek utama dalam penelitian ini dikarenakan perannya yang signifikan dalam melakukan pembinaan dan pelatihan para calon Paskibraka selama proses pendidikan berlangsung.

Pendekatan yang dilakukan dalam penelitian ini adalah pendekatan kualitatif, yaitu suatu proses penelitian dan pemahaman yang berdasarkan pada metodologi yang menyelidiki suatu fenomena sosial dan masalah manusia. Prosedur penelitian ini menghasilkan data deskriptif berupa katakata lisan, catatan-catatan yang berhubungan dengan makna, nilai serta pengertian dari orang-orang atau perilaku yang dapat diamati, metode ini lebih mudah menyesuaikan dengan kondisi lapangan, lebih peka terhadap perubahan pola/nilai, dan bahkan data yang ada di lapangan (Kaelan, 2012:36).

Penelitian ini menggunakan beberapa teknik untuk mengumpulkan data, di antaranya observasi dengan melakukan pengamatan secara langsung terhadap pembinaan pemuda PPI yang berperan langsung di masyarakat secara mendalam, data harus tergambarkan secara jelas, gambaran yang cukup membuat pembaca memiliki gambaran utuh (Patton, 2009: 10 - 11). Wawancara merupakan teknik pengumpulan data yang digunakan untuk mendapatkan data kualitatif serta beberapa keterangan yang tidak didapat dari data sekunder. Teknik ini dilakukan terhadap narasumber yang berkompeten dengan penelitian. Wawancara dilakukan langsung atau pendalaman dan penggalangan informasi dengan narasumber. Dalam riset ini, narasumbernya merupakan staf Dinas Pemuda dan Olahraga Pemkab Bandung serta pengurus dan alumni organisasi PPI Kabupaten Bandung.

Studi pustaka, dokumentasi dan penelusuran laman on-line dilakukan untuk mendapatkan data sekunder yang diperoleh dengan memanfaatkan berbagai dokumen yang dimiliki Dispora dan pengurus PPI Kabupaten Bandung serta literatur yang lainnya yang dianggap relevan. Dengan metode penelitian deskriptif di mana hasil penelitian ini memaparkan obyek yang diteliti (orang, lembaga atau yang lainnya) yang berdasarkan fakta di lapangan. Tujuan untuk mendeskripsikan, mencatat, menganalisis, dan menginterpretasikan kondisi-kondisi yang terjadi dilaksanakan saat penelitian berlangsung (Mardalis, 1990: 26).

Data penelitian yang berhasil didapatkan selama riset berlangsung kemudian dianalisis dan diinterpretasikan sesuai dengan maksud dari penelitian ini. Data tersebut yang nantinya dipilah menjadi bagian proses penanaman nilai-nilai bela negara dalam kegiatan pembentukan seorang calon Paskibraka dan implikasinya terhadap ketahanan pribadi 
para alumni Paskibraka yang telah menjadi PPI.Dalam hal ini dicari korelasi antara internalisasi nilai-nilai bela negara yang berdampak dalam membentuk ketangguhan karakter dan kepribadian pemuda Paskibraka.

\section{PEMBAHASAN}

Hubungan antara negara, masyarakat, dan warga negara merupakan suatu bentuk interaksi yang memiliki peranan dan fungsi masing-masing di dalam interaksi kehidupan berbangsa dan bernegara. Warga negara membutuhkan kehadiran negara untuk menjamin hak-hak hidupnya agar dapat tertunaikan. Negara juga membutuhkan partisipasi pembelaan dan kehadiran warga negaranya untuk kepentingan menjaga eksistensi negara dan juga sebagai subyek sekaligus obyek dalam rangka mencapai tujuannya.

Merujuk pada Permepora Nomor 65 tahun 2015, menerangkan bahwa Pasukan Pengibar Bendera Pusaka atau Paskibraka merupakan sekumpulan pemuda-pemudi setingkat SMA yang mengibarkan bendera pusaka pada upacara detik-detik proklamasi baik di tingkat nasional, provinsi maupun kabupaten/kota. Paskibraka merupakan generasi muda yang mendapat kehormatan bertugas sebagai pengibar dan penurun bendera merah putih dalam rangka memperingati detik-detik proklamasi kemerdekaan Republik Indonesia. Asal mula Paskibraka tidak bisa lepas dari upacara pembacaan teks Proklamasi Kemerdekaan RI pada tanggal 17 Agustus 1945.

Dengan terbentuknya organisasi kepemudaan yang merupakan alumni dari Paskibraka Kabupaten Bandung menjadi Purna Paskibraka Kabupaten Bandung, membuat terjalinnya komunikasi yang intens diantara para alumninya. Organisasi PPI ini sering dilibatkan dalam memelopori dan menyukseskan banyak kegiatan kepemudaan dan protokoler yang digelar oleh pemerintah daerah. Kuatnya koordinasi dan hirarki yang telah terbentuk selama proses pendidikan telah menumbuhkan rasa kebersamaaan yang tinggi atau jiwa korsa yang berakibat munculnya soliditas dan solidaritas yang tinggi diantara para anggota organisasinya, sehingga cukup mudah dalam hal mobilisasi anggotanya saat organisasi ini dibutuhkan oleh lingkungannya.

Ketika dimulainya proses seleksi calon anggota Paskibraka baru, para alumni yang tergabung dalam Purna Paskibraka Indonesia (PPI) Kabupaten Bandung sudah mulai terlibat membantu panitia seleksi yang merupakan staf pegawai Dispora Kabupaten Bandung. Mengingat animo calon peserta yang tinggi dan merupakan ajang bergengsi bagi tiap sekolah di jajaran Kabupaten Bandung, maka kehadiran dan bantuan personil PPI Kabupaten Bandung yang terdiri dari berbagai tahun angkatan sangat membantu staf Dinas Kepemudaan dan Olahraga Kabupaten Bandung dalam seluruh rangkaian prosesnya.

Untuk tahapan kegiatan penerimaan seleksi sebelum memasuki pemusatan pelatihan, dilaksanakan dalam beberapa rangkaian kegiatan. Setelah dinyatakan lulus seleksi dan terpilih oleh Dispora Kabupaten Bandung, maka para calon siswa akan menjalani program latihan pendahuluan di Lapangan Upacara Upakarti di Komplek Pemerintahan Kabupaten Bandung selama 3 bulan yang dilaksanakan setiap hari minggu dari pagi hingga sore hari. Latihan drill ini merupakan kegiatan pendahuluan selalu dilaksanakan di lapangan ini agar para calon Paskibraka (Capaska) mengenal bahwa nanti di tempat inilah puncak tugas mereka, dimana 
saat itu mereka akan bertugas mengibarkan Bendera Merah Putih. Pasca melaksanakan tugas mulianya, mereka otomatis akan mengemban predikat baru, dari semula adalah pemuda Paskibraka menjadi pemuda Purna Paskibraka Indonesia (PPI).

\section{Pembinaan dan Latihan}

Merujuk kepada Panduan Kegiatan Paskibraka yang termuat dalam Permenpora 0065 Tahun 2015, ada beberapa kegiatan pembinaan yang idealnya diterapkan dan dilakukan saat proses pemusalatan dan latihan sewaktu dilaksanakan karantina dengan beberapa penyesuaian kegiatan dari para pembinanya. Proses pendidikan atau dapat juga disebut pembalokan sebagai kegiatan intensif dalam pembinaan dasar dari Capaska menjadi seorang Paskibrka di Kabupaten Bandung ini melibatkan pihak ketiga yang merupakan instansi militer.

Dispora Kabupaten Bandung menjalin kerjasama dengan pihak TNI AU, khususnya dengan Pusat Pendidikan dan Latihan Korp Pasukan Khas TNI AU (Pusdiklat Paskhasau) yang berlokasi di Lanud Sulaiman. Pemilihan instansi ini dikarenakan memiliki instruktur berpengalaman dan memiliki fasilitas latihan dan asrama yang representatif untuk turut serta mendidik dan membina para calon paskibraka untuk mempersiapkan diri dalam melaksanakan tugas utamanya sebagai pengibar Bendera Merah Putih pada puncak peringatan Hari Kemerdekaan Republik Indonesia yang dihelat pada tanggal 17 Agustus setiap tahunnya.Para Capaska ini akan menjalani masa karantina selama 14 hari dengan mengikuti pola dan tradisi pembinaan kedisiplinan secara semi militer yang merupakan nafas pokok dari kegiatan Paskibraka.
PPI Kabupaten Bandung dengan rekomendasi Dispora memegang peranan yang sangat signifikan dalam rangkaian kegiatan ini, yang terbagi menjadi dua tugas, yaitu pembinaan dan latihan luar dan dalam (Binlat Luar dan Dalam). Binlat luar bertugas membina kemampuan baris berbaris capaska dan bekerjasama dengan pelatih dari TNI saat sudah memasuki masa pemusatan latihan. Binlat dalam seluruhnya dilaksanakan oleh senior PPI yang mengawasi dan membina kegiatan di dalam barak atau asrama, mulai dari kebersihan, kerapihan, table manner dan penanaman sikap dan karakter sebagai seorang Paskibraka.

Dalam kegiatan karantina ini disimulasikan menjadi sebuah perkampungan yang disebut sebagai Desa Bahagia. Di tempat inilah mulai diterapkan lebih intensif mengenai nilainilai luhur dari Pancasila selaku dasar negara Indonesia, penanaman wawasan kebangsaan, pemahaman akan nilai-nilai bela negara, serta dilaksanan kegiatan secara bersama-sama atau gotong royong dalam setiap acara. Di simulasi Desa Bahagia ini juga ditunjuk kepala atau ketua angkatan yang disebut sebagai Pak Lurah dan $\mathrm{Bu}$ Lurah yang merepresentasikan struktur hirarki organisasi.

Mereka dilatih dan dididik supaya mampu menjadi seorang pemuda berkarakter tangguh yang berkepribadian Pancasila. Setiap hari kemampuan fisik dan mental diasah dan dilatih untuk menumbuhkan segala potensi yang terdapat dalam diri pemuda Capaska. Pak Lurah dan Bu Lurah, serta ketua harian yang ditunjuk memiliki tanggungjawab sebagai leader dalam rangkaian kegiatan harian. Di pundak mereka itulah rekan-rekan Capaska diorganisir agar tertib dan disiplin mengikuti seluruh rangkaian kegiatan baik di lapangan maupun dalam bina kelas. 
Dalam penanaman karakter agar menjadi Pemuda Paskibraka yang tangguh, dengan merujuk pada Permenpora dan aturan kesatrian TNI maka pembina dan pengasuh dari kedua pihak melaksanan rangkaian kegiatan pendidikan dan pelatihan selama proses karantina berlangsung. Rangkaian kegiatan pendidikan dan pelatihan tersebut adalah sebagai berikut.

Pertama, kegiatan pagi.Kegiatan bangun pagi merupakan awal dari segala kegiatan yang dilaksanakan untuk menanamkan nilai kedisiplinan yang terukur semenjak pagi hari.

Kedua, kegiatan ibadah pagi dan malam. Ibadah adalah hal yang utama dan semua capaska ditanamkan tanggang rasa terhadap sesama pemeluk agama.

Ketiga, olahraga umum / aerobik.Lari pagi dan senam adalah bagian dari olahraga wajib yang harus diikuti oleh semua capaska yang bertujuan untuk memelihara kesamaptaan jasmani, juga untuk mengkondisikan jiwa capaska untuk tetap semangat mengikuti kegiatan yang cukup padat.

Keempat, menjaga kebersihan diri dan lingkungan.Dalam masa karantina capaska dituntut mampu melakukan kegiatan pembersihan, baik diri maupun lingkungannya. Fasilitas kamar mandi yang ada di barak / asrama terbatas maka perlu kepedulian dalam hal kebersihan sehingga dapat menanamkan rasa kebersamaan para capaska.

Kelima, table manner.Semua kegiatan makan pagi, makan siang, dan malam dilaksanakan secara formal dengan mengikuti tradisi militer dan dilakukan bersama-sama untuk menggalang kerukunan sesama capaska, pembina dan dengan pelatih.

Keenam, latihan di lapangan.Peserta dilatih oleh tim pelatih yang telah ditunjuk oleh kesatuan, diawali dengan latihan dasar yang merujuk kepada PBB (Peraturan BarisBerbaris) TNI. Latihan kering (Drill) ini dilaksanakan setiap hari secara berulangulang agar tercipta keselarasan antar pasukan upacara, sehingga memunculkan kesamaan gerakan, keserasian langkah dan sikap dalam melaksanakan tugas pokok nantinya.

Ketujuh, wawasan kebangsaan dan bela negara.Di sela kegiatan maupun pada saat malam hari dilaksanakan kegiatan pembinaan mental ideologi berupa penanaman doktrindoktrin tentang wawasan kebangsaan dan kesadaran bela negara yang merupakan satu kesatuan dari keseluruhan kegiatan dan pelatihan. Kedudukan penanaman wawasan kebangsaan ini sangat dikuatkan karena merupakan ruh semangat yang timbul dari eksistensi dan dinamika bangsa. Sinar yang muncul dari wawasan kebangsaan akan menerangi pola pikir, pola tindak dan pola sikap seluruh warga dalam kehidupan bernegara dan berbangsa. (Martodirjo, 2008:3).

Sehari sebelum pengibaran bendera pada 17 Agustus dilaksanakan pengukuhan yang secara simbolis merupakan tanda berakhirnya pendidikan dan latihan, artinya mereka telah resmi dilantik dari seorang capaska (Calon Paskibraka) menjadi Paskibraka (Pasukan Pengibar Bendera Pusaka). Upacara pengukukan secara resmi dipimpin oleh Bupati Kabupaten Bandung dan dihadiri jajaran pimpinan daerah dan perwakilan dari instansi TNI/POLRI. Setiap peserta dikukuhkan dengan mengucapkan "Ikrar Putra Indonesia” sambil memegang Sang Merah Putih, kemudian menciumnya sebagai kiasan kesiapan untuk senantiasa menjaga, setia \& membelanya dengan segenap jiwa raga. Tanda pengukuhan berupa sabuk keahlian atau "kendit" yang dililitkan ke pinggang dan diikatsimpulkan di bagian depan perut. 


\section{Pembinaan Kegiatan PPI}

Purna Paskibraka Indonesia (PPI) sebagai organisasi kemasyarakatan yang memiliki tujuan untuk membentuk manusia Indonesia yang berjiwa Pancasila serta patuh dan taat kepada Negara Kesatuan Republik Indonesia melakukan berbagai kegiatan dalam rangka mencapai tujuannya. Serangkaian kegiatan dan pelatihan yang telah dialami oleh para alumni pemuda Paskibraka Kabupaten Bandung dalam penanaman disiplin, wawasan kebangsaan dan pendidikan bela negara pada saat pemusatan latihan sangat membekas dalam hati sanubari mereka. Hal ini tetap tercermin saat mereka melanjutkan pengabdiannya menjadi PPI Kabupaten Bandung selaku sebuah organisasi kemasyarakatan.

Kegiatan yang dilakukan oleh PPI Kabupaten Bandung akan diklasifikasikan menjadi empat model kegiatan, yaitu model kegiatan yang bersifat pembinaan ideologi kebangsaan, model kegiatan yang bersifat sosial, model kegiatan yang bersifat pembinaan kesamaptaan, dan model kegiatan yang bersifat aksi. Empat model kegiatan ini merupakan bentuk partisipasi pemuda Purna Paskibraka Indonesia dalam rangka bela negara selaku organisasi kepemudaan. Keempat model ini merupakan penjabaran dari penanaman nilai kehidupan berbangsa dan bernegara.

Kegiatan bersifat pembinaan ideologis yang dilakukan oleh Purna Paskibraka Indonesia (PPI) Kabupaten Bandung adalah rangkaian kegiatan yang puncaknya pada Upacara Bendera 17 Agustus dalam rangka hari peringatan kemerdekaan Republik Indonesia setiap tahunnya. Sang Merah Putih yang berkibar menjadi saksi akan perjuangan mereka selama berbulan-bulan karena pengibaran ini representasi perjalanan panjang sejak proses seleksi, pendidikan dan latihan, hingga puncaknya pada momen pengibaran bendera. Perjalanan panjang yang penuh dengan dinamika merupakan sebuah pengorbanan. Hari ini Sang Saka Merah Putih dapat berkibar dengan sempurna di langit Bumi Pertiwi, akan tetapi di masa yang lalu para pendiri bangsa ini, para pejuang yang mendirikan negara ini mengibarkan bendera merah putih dengan nyawa sebagai taruhannya.

Di Kabupaten Bandung setiap tahun diadakan upacara peringatan Hari Kemerdekaan 17 Agustus dan setiap tahunnya pula mengirimkan delegasinya untuk mengikuti seleksi Paskibraka tingkat Provinsi dan atau bersaing untuk tingkat nasional. Untuk mewujudkan hal tersebut PPI Kabupaten Bandung memiliki peran yang penting untuk andil dalam menjaring potensi pemuda-pemudi kelas X setingkat SMA, MA dan SMK terbaik di Kabupaten Bandung, demi membentuk sebuah Paskibraka Kabupaten Bandung dan memberikan putraputri terbaik yang bisa mewakili Kabupaten Bandung dalam seleksi tingkat provinsi maupun nasional.

Kegiatan yang pertama adalah seleksi. Seleksi ini dilakukan sejak bulan Maret pada tahun berjalan. Proses seleksi melalui dua tahapan, pada seleksi tahap pertama dilakukan pemeriksaan berkas administrasi, tes akademis berupa wawasan kebangsaan, penilaian ulang tinggi, berat, serta postur badan calon peserta dan tes wawancara awal oleh para pemuda PPI. Tahapan yang kedua terdiri dari tes akademis, kesegaran jasmani dan tes baris-berbaris.

Model Pemusatan Latihan ini adalah berbentuk kegiatan pengasramaan atau karantina yang mengikuti model Desa Bahagia yang diamanatkan sesuai Pemenpora Nomor 65 Tahun 2015, dimana hal ini dirasa penting 
untuk sesegera mungkin calon paskibraka Kabupaten Bandung untuk beradaptasi dengan tuntutan tugas mereka. Di asrama ini mereka akan melaksanakan kegiatan yang bersifat hirarki dimana akan dipilih ketua angkatan dengan sebutan Pak Lurah dan Bu Lurah. Personil capaska yang sudah ditunjuk ini akan bertanggungjawab penuh atas kedisiplinan dan kekompakan rekan-rekannya selama proses karantina.

Kegiatan saat pemusatan latihan ini menggunakan standar Peraturan Baris Berbaris Tentara Nasional Indonesia (PBB TNI). Kegiatan dalam latihan terdiri dari tiga kegiatan, yaitu kegiatan fisik berupa senam dan lari, kegiatan baris berbaris, dan kegiatan di dalam ruangan. Kegiatan di dalam ruangan ini lebih menekankan pada penanaman rasa nasionalisme, yaitu dengan menyampaikan materi seputar wawasan kebangsaan dan internalisasi nilai-nilai bela negara.

Pada tahapan ini ditanamkan juga tentang pendidikan kedisiplinan, penanaman nilai-nilai bela negara dan wawasan kebangsaan, karakter kepemimpinan, pengetahuan kepaskibrakaan, dan kepemudaan serta pendidikan karakter lainnya yang menunjang dalam tugas dan penerapan kelak saat berpartisipasi dalam kehidupan masyarakat. Doktrin dan materi ini disampaikan oleh pelatih maupun pembina yang telah memiliki kompetensi di bidangnya dan berasal dari intansi yang terkait dengan kegiatan ini.

Setelah masa pendidikan dan latihan usai, kegiatan selanjutnya adalah pengibaran Bendera Sang Merah Putih pada Upacara Besar 17 Agustus. Kegiatan pengibaran bendera didahului dengan gladi bersih yang dilanjutkan dengan pengukuhan pasukan yang dilaksanakan pada tanggal 16 Agustus. Pengukuhan pasukan dilakukan dengan prosesi mencium Bendera Merah Putih. Upacara Peringatan Kemerdekaan 17 Agustus yang dihelat setiap tahun merupakan upacara yang sakral. Pada upacara ini semua pandangan mata akan tertuju ke Paskibraka. Seluruh elemen masyarakat berkumpul di kompleks pusat Pemerintahan di Lapangan Upacara Pemerintah Kabupaten Bandung yang dihadiri segenap undangan yaitu pejabat Forum Komunikasi Pimpinan Daerah (FKPD) hingga disaksikan oleh masyarakat se-Kabupaten Bandung. Pada upacara ini, orang tua para personil Paskibraka juga dihadirkan. Tujuannya agar orang tua merasakan kebanggaan melihat anaknya bertugas sebagai Paskibraka. Gerakan yang dilakukan Paskibraka pada waktu upacara memiliki makna tersendiri.

Mengikuti tata upacara militer yang berlaku di Indonesia, formasi pasukan upacara terbagi menjadi tim pasukan upacara terbagi atas pasukan 17 selaku pendamping, pasukan 8 selaku pasukan inti pembawa bendera dan pasukan 45 selaku pasukan pengawal yang berasal dari TNI atau POLRI, yang meski pada pelaksanaannya berpisah namun langkah geraknya tetap sama. Gerakan ini memberi makna Bhinneka Tunggal Ika yang berarti bahwa Indonesia ini berbeda-beda namun tetap satu dan dipersatukan akan tujuan yang satu. Dengan wilayah yang sangat luas, persepsi yang sama tentang kebhinnekaan harusdimilikiagar tidak mudah dipecah belah. Setelah melaksanakan tugas sebagai Paskibraka pada upacara 17 Agustus, para anggota pasukan dilantik menjadi Purna Paskibraka Indonesia.

Kegiatan bersifat sosial baik dalam skala aktif maupun pasif yang dilakukan oleh Purna Paskibraka Indonesia Kabupaten Bandung dalam rangka pengaplikasian kepedulian terhadap lingkungan sekitar 
serta menstimulasi kalangan generasi muda lainnya untuk dapat turut serta berkarya bagi masyarakat. Keaktifan anggota PPI Kabupaten Bandung juga turut serta dalam mengikutsertakan seluruh kadernya, baik yang masih duduk di bangku sekolah maupun para alumninya untuk mengikuti berbagai kegiatan atau seminar yang diselenggarakan oleh instansi pemerintah. Salah satunya adalah mengikuti penyuluhan Seminar Pencegahan Narkoba (Narkotika dan Obat-Obat Terlarang) yang menyasar generasi muda. Para anggota PPI Kabupaten Bandung yang telah melewati suatu pelatihan di kala menjadi seorang calon Paskibraka diharapkan tidak terperngaruh dan terjerumus ke dalam lingkaran narkoba perusak masa depan bangsa. Bahkan seharusnya para anggota PPI Kabupaten Bandung ini menjadi agen pelopor dalam menangkal segala jenis pengaruh-pengaruh sosial yang negatif yang mengancam kehidupan berbangsa dan bernegara.

Kegiatan bersifat kebugaran jasmani atau kesamaptaan yang dilakukan oleh Purna Paskibraka Indonesia Kabupaten Bandung adalah mengadakan Lomba Peraturan Baris Berbaris (LPBB) tingkat Kabupaten Bandung yang diberi nama LPBB PPI untuk seluruh sekolah setingkat SMA / SMK / MA seKabupaten Bandung yang diselenggarakan di Lapangan Upacara Pemerintahan Kabupaten Bandung yang ditunjuk PPI Kabupaten Bandung, karena dinilai memiliki tempat lapangan upacara yang representatif dan selalu digunakan dalam perhelatan protokoler.

LPBB PPI diadakan secara rutin setiap satu tahun sekali bekerjasama dengan Dinas Kepemudaan dan Olahraga dan Dinas Pendidikan Kabupaten Bandung, mengingat acara ini melibatkan siswa yang berstatus sebagai pelajar. Selain memperebutkan gelar juara tingkat kabupaten, kegiatan ini juga merupakan event bergengsi yang merupakan seleksi Peleton Paskibraka tingkat SMA/SMK/MA tingkat Kabupaten Bandung untuk mengirimkan wakilnya ke perlombaan di tingkat yang lebih tinggi, yaitu LPBB tingkat Provinsi Jawa Barat. LPBB PPI ini dilaksanakan dengan maksud dan tujuan: (1). Meningkatkan kedisiplinan, kesehatan jasmani, dan kreativitas di kalangan siswa SMA / sederajat; (2). Memperdalam rasa cinta tanah air serta mempertebal semangat kebangsaan dan kesatuan di kalangan siswa SMA / sederajat; (3). Menumbuhkan rasa dinamisme, sportif, kreatif, dan inovatif dalam bidang tata upacara bendera dan baris berbaris; (4). Mengokohkan rasa persatuan, kekompakkan dan kedisiplinan siswa melalui tata upacara bendera dan baris berbaris; (5). Meningkatkan kualitas dan menumbuhkan animo dari peserta paskibra sekolah untuk mengikuti seleksi menjadi Paskibraka Kabupaten Bandung.

Pasca selesai melaksanakan tugas pokoknya, para Purna Paskibraka Kabupaten Bandung tetap terlibat dalam kegiatan protokoler dan seremonial yang dihelat oleh instansi pemerintah daerah. Dalam kegiatannya, Peringatan Hari Besar Nasional (PHBN) selalu melibatkan anggota Purna Paskibraka Indonesia. Kegiatan PHBN memang identik dengan pelaksanaan upacara di lapangan, sehingga keahlian Purna Paskibraka ini tetap digunakan selaku regu pengibar Bendera Sang Merah Putih di tingkat kabupaten yang merupakan momen sakral dalam suatu upacara kenegaraan.

\section{Internalisasi Nilai-Nilai Bela Negara}

Sesuai dengan yang tercantum dalam Pasal 30 UUD 1945, warga negara memiliki hak dan kewajiban untuk melakukan kegiatan bela negara. Kegiatan yang memiliki tujuan 
untuk meningkatkan rasa nasionalisme dan patriotisme harus diikuti oleh setiap warga negara terutama para generasi muda (Basrie, 1998 : 6). Cinta tanah air merupakan perwujudan dari semangat patriotisme dan nasionalisme, oleh sebab itu ketiganya mempunyai hubungan erat yang tidak terpisahkan.

Dengan memiliki sifat cinta tanah air, bela negara menjadi sesuatu yang penting, sehingga menyebabkan setiap warga negara ingin meraih dan berpartipasi sebagaimana yang terjadi pada masa revolusi kemerdekaan. Generasi muda harus memiliki pemahaman dan kesadaran terhadap kegiatan bela negara. Pada uraian sebelumnya telah dijelaskan bahwa para pemuda yang tergabung dalam Purna Paskibraka Indonesia Kabupaten Bandung melakukan berbagai kegiatan dan aksi dalam rangka kegiatan bela negara. Kegiatan-kegiatan tersebut dilakukan untuk memberikan pemahaman tentang bela negara kepada para anggotanya dan juga kepada masyarakat. Penanaman nilai-nilai bela negara juga dilakukan lewat gemblengan oleh para senior PPI saat latihan mingguan maupun dari pelatih TNI di Pusdiklat Paskhasau pada saat pemusatan latihan (Suryaningrat, 2018 : 143).

Nilai-nilai yang didapat oleh para anggota Purna Paskibraka Indonesia Kabupaten Bandung adalah fokus, kedisiplinan, tanggungjawab, kekeluargaan, tangguh, dan kebersamaan. Nilai-nilai itu didapat lewat prosesi upacara bendera dimana upacara bendera merupakan sebuah rangkaian kegiatan yang diakhiri dengan prosesi yang sakral. Pada kegiatan PBB, penanaman nilai-nilai kebangsaan melalui gerakan-gerakan yang diajarkan baik gerakan dasar, gerakan berjalan, maupun gerakan variasi formasi. Gerakangerakan PBB yang mengikuti gerakan PBB
TNI dan Polri ini diajarkan di Paskibraka yang hakikatnya mengandung nilai dan makna tentang kehidupan berbangsa dan bernegara.

Gerakan-gerakan tersebut dalam latihan lapangan Paskibraka meliputi gerakan dinamis dalam bentuk tiga kelompok pasukan, formasiformasi gerakan, termasuk hormat bendera, gerakan sikap sempurna, menyanyikan yel-yel sebagai penggugah semangat, dan hingga hukuman di tempat bagi yang kurang fokus dan disiplin. Gerakan hormat bendera bermakna penghormatan terhadap bangsa dan negara Indonesia. Hormat bendera merupakan sebuah sikap menghormati dan menghargai perjuangan para pendahulu bangsa, serta pengakuan terhadap negara dan pemerintahan yang sah. Gerakan ini menimbulkan rasa kebanggaan bagi anggota Paskibraka. Bagi anggota Paskibraka, gerakan penghormatan terhadap Merah Putih mampu meningkatkan rasa cinta kepada Indonesia dan juga memberikan pengaruh pada sikap dan perilaku mereka sehari-hari.

Gerakan sikap sempurna bermakna siap untuk tetap sigap dan siap sedia untuk bela negara. Sikap sempurna yang ditunjukkan dengan cara berdiri tegap, pandangan lurus ke depan, dada dibusungkan memberikan makna bahwa Paskibraka sebagai anak bangsa siap melaksanakan apa yang diminta oleh negara dan rela berkorban untuk kepentingan bangsa dan negara. Kemudian di dalam Paskibraka, barisan pun harus lurus. Lurusnya barisan merupakan perwujudan dari nilai persatuan dan kesatuan.

Anggota Paskibraka berasal dari latar belakang sekolah yang beragam, tapi ketika berada dalam barisan mereka adalah satu kesatuan yang utuh dimana barisan harus lurus dan gerakan yang dilakukan harus sama dan serempak. Barisan lurus ini memiliki 
makna bahwa Indonesia yang terdiri dari berbagai macam suku, agama, dan ras harus bersatu. Ketika berada dalam koridor sebagai bangsa Indonesia maka nilai yang dibawa adalah nilai-nilai dan konsensus yang telah disepakati bersama. Tidak boleh masingmasing kelompok memaksakan nilai-nilai yang dimilikinya.

Selain gerakan-gerakan baris berbaris, capaska yang mengikuti pendidikan Paskibraka juga diajarkan variasi materi baris berbaris. Salah satu variasi materi baris-berbaris yang diajarkan kepada para anggota Paskibraka adalah lagu-lagu mars perjuangan khas militer dan teriakan berupa penyemangat atau yelyel. Lagu-lagu mars dan yel-yel merupakan senandung yang berisi kata-kata pembakar semangat, diikuti dengan gerakan badan ketika menyanyikan lagu dan yel-yel tersebut. Lagu-lagu mars dan yel-yel ini merupakan perwujudan dari semangat dalam kegiatan kelompok di lapangan, lebih lanjutnya menjadi semboyan dalam program membela tanah air. Lagu-lagu mars dan yel-yel ini dinyanyikan saat jeda latihan kosong, menunggu waktu extrafooding, dan momen lainnya yang dirasa perlu oleh para pembina dan pelatih.

Di dalam barisan Paskibraka tentunya tidak terlepas dari adanya kesalahan baik terutama latihan tugas untuk upacara bendera. Kesalahan yang dilakukan oleh anggota Paskibraka ketika berada di dalam barisan akan diberikan hukuman fisik berupa push up. Hukuman yang diberikan ini bukan dimaksudkan untuk melakukan kekerasan, namun lebih kepada penyadaran diri dan pembinaan terhadap anggota Paskibraka bahwa tidak boleh terdapat kesalahan sedikitpun.

Hukuman di dalam Paskibraka memiliki ciri khusus yang bersifat kebersamaan, artinya bila ada salah satu anggota pasukan yang salah dan menerima hukuman, maka seluruh anggota dalam pasukan tersebut juga mendapatkan hukuman yang serupa. Dari sini dapat dilihat bahwa hukuman di dalam Paskibraka merupakan perwujudan pembinaan rasa kebersamaan dalam keberagaman. Paskibraka yang terdiri dari beragam latar belakang, ketika salah satu anggota pasukan mendapatkan hukuman maka yang lain pun ikut merasakan hukuman yang sama. Hal ini bermakna bahwa para anggota Paskibraka harus memiliki cara pandang yang satu sebagai masyarakat Indonesia.

Sebuah organisasi akan terus eksis dan berkembang ketika para anggotanya memiliki kesadaran penuh terhadap peran yang dimilikinya. Kesadaran dan eksistensi suatu organisasi memiliki hubungan yang erat. Warga negara yang memiliki kesadaran terhadap bela negara akan membuat negara memiliki ketahanan nasional yang kuat. Kesadaran muncul setelah seseorang memiliki pemahaman terhadap sesuatu.

\section{Paskibraka Menanamkan Rasa Cinta Tanah Air}

Paskibraka merupakan salah satu media dalam menanamkan rasa cinta tanah air terhadap generasi muda terutama usia sekolah setingkat SMA / Sederajat karena usia ini mereka telah menuju usia matang dan mampu bersikap dewasa. Dalam kegiatan penggemblengan Paskibraka, penanaman rasa cinta tanah air ini dilakukan secara terus menerus mulai dari kegiatan seleksi awal, latihan rutin mingguan, karantina di Pemusatan Latihan, acara pokok upacara bendera dalam peringatan Hari Kemerdekaan Republik Indonesia tanggal 17 Agustus, upacara PHBN dan kegiatan protokoler lainnya, dimana selalu ada bendera merah putih dan lagu kebangsaan Indonesia dikumandangkan. 
Di dalam kegiatan pelatihan, terutama saat pemusatan latihan, materi-materi wawasan kebangsaan, bela negara, sejarah bendera merah putih, lagu kebangsaan Indonesia dan perlakuannya, lambang negara dan perlakuannya serta bahasa Indonesia sehingga dengan lebih mengenal negaranya Indonesia diharapkan pemuda Paskibraka akan bisa mencintai tanah airnya. Tanpa mengenal terlebih dahulu Indonesia, maka peserta Paskibraka tidak akan dapat mencintai tanah airnya secara penuh.

\section{Paskibraka Menumbuhkan Kesadaran Berbangsa dan Bernegara.}

Karakter yang diperlukan untuk membangun kesadaran berbangsa dan bernegara ini meliputi berbagai tindakan mewujudkan terciptanya masyarakat sipil yang menghormati hak-hak individu (Mu'in, 2016: 211-247). Sejak awal mengikuti seleksi menjadi calon anggota Paskibraka yang berbeda secara fisik, agama, suku dan asal sekolahnya, yang kemudian setelah melalui berbagai tahapan seleksi hanya tersisa 54 orang. Akhirnya mereka menjadi sebuah kelompok pasukan, dimana dibentuknya kelompok ini terus bersama dalam seluruh kegiatan Paskibraka sejak awal lulus seleksi hingga saat pengibaran tiba. Dengan menjadi kelompok Paskibraka, hal ini mengajarkan untuk menyadari dan memahami keragaman individu yang ada dalam regu tersebut baik keragaman budaya, suku, agama, bahasa dan adat istiadat masing-masing peserta.

Dalam proses penggemblengan, para peserta dituntut untuk bisa mengikuti seluruh rangkaian kegiatan yang terjadwal cukup padat. Kemampuan dan potensi pribadi setiap peserta diasah sebaik mungkin untuk menumbuhkan peserta Paskibraka yang tanggap, tangguh dan trengginas selaku pasukan pengibar bendera pusaka. Keterampilan memimpin (leadership skill) dan kepercayaan diri (confidence) diasah secara terus menerus dalam setiap rangkaian kegiatan.

\section{Paskibraka Menanamkan Kesetiaan Kepada Pancasila sebagai Ideologi Negara.}

Pancasila merupakan dasar negara yang dijadikan pandangan hidup bangsa Indonesia dan ideologi negara. Hal ini berarti apa yang terkandung dalam Pancasila harus pahami dan diaplikasikan oleh setiap warga negara Indonesia termasuk anggota Paskibraka. Dalam Anggaran Dasar Paskibraka disebutkan bahwa asas gerakan Paskibraka adalah Pancasila, hal ini berarti bahwa Pancasila juga menjadi landasan dalam setiap kegiatan Paskibraka. Pemahaman akan nilai-nilai Pancasila dalam kehidupan berbangsa dan bernegara yang dipelajari akan membentuk karakter pemuda Indonesia yang tangguh.

\section{Paskibraka Menumbuhkan Sikap Rela Berkorban untuk Bangsa dan Negara}

Pendidikan dalam Paskibraka berfungsi untuk menumbuhkan sikap rela berkorban untuk bangsa dan negara diwujudkan melalui latihan dalam lingkup kecil yaitu kesadaran individu itu sendiri, dimana setiap individu yang tergabung dalam satu kelompok harus bisa mendahulukan kepentingan bersama di atas kepentingan pribadi atau individu. Hal ini akan membiasakan capaska untuk bisa berinteraksi dengan orang lain, menghargai orang lain dan kepentingannya serta rela berkorban untuk kepentingan bersama.

Hal ini akan lebih ditekankan lagi pada saat kegiatan pemusatan latihan ini yang bersistem karantina, dimana siswa dihadapkan pada situasi dan kondisi yang sama 
sehingga mereka akan memiliki rasa senasib sepenanggungan untuk bisa mewujudkan tujuan bersama. Termasuk dalam persiapan menjelang kegiatan pemusatan latihan, mereka dituntut untuk meluangkan waktu, tenaga pikiran dan kesiapan materi setiap hari Rabu dan Minggu untuk mempersiapkan segala sesuatunya yang merupakan kepentingan bersama dalam satu kelompok, demi menciptakan kekompakan atau jiwa korsa.

Dengan pembelajaran ini diharapkan calon paskibraka dapat mengaplikasikannya dalam lingkup yang lebih luas yaitu dalam masyarakat dan lebih luas lagi dalam kehidupan berbangsa dan bernegara. Jadi dalam hal ini Paskibraka berperan dalam menumbuhkan sikap rela berkorban untuk bangsa dan negara sesuai dengan indikator kerelaan untuk meluangkan waktu, tenaga, pikiran dan materi untuk kepentingan bersama atau bangsa dan negara serta mendahulukan kepentingan bersama di atas kepentingan pribadi atau golongan.

\section{Paskibraka Berperan Membekali Kemampuan Dasar Pendahuluan Bela Negara}

Kemampuan dan kesiapan awal untuk bela negara ini terdiri dari kemampuan fisik dan mental sehingga ketika terjadi ancaman setiap individu minimal telah memiliki persiapan. Kesiapan fisik tentunya dengan fisik atau badan yang sehat dan kuat untuk dapat mengatasi kesulitan, dan mengingat bahwa saat seleksi awal penerimaan Capaska bahwa kesamaptaan atau kebugaran jasmani adalah tolok ukur penilaian yang sangat menentukan.

Kesiapan mental juga tidak luput menjadi perhatian karena ini berarti setiap individu harus memiliki kecerdasan baik intelektual, spiritual, emosional, kemampuan bertahan hidup dan kemampuan mengatasi kesulitan. Paskibraka berperan banyak dalam membekali siswa agar memiliki kemampuan awal yang dibutuhkan untuk bela negara. Mulai dari kesiapan fisik dimana dalam Paskibraka hampir semua tahapan kegiatan melibatkan kekuatan fisik yang prima. Kegiatan-kegiatan tersebut diantaranya adalah kegiatan baris-berbaris, lari pagi, samapta dan olahraga umum di sore hari. Dengan kegiatan-kegiatan tersebut diharapkan calon Paskibraka memiliki kemampuan fisik yang cukup sehingga ini juga menjadi bekal bagi kemampuan awal bela negara.

Kemudian kemampuan mental dalam bela negara dimulai dari kecerdasan spiritual dalam Paskibraka merupakan pondasi awal yang harus dimiliki setiap calon anggota Paskibraka. Di sini calon anggota Paskibraka harus memiliki spiritual yang tinggi sebagai landasan pelaksanaan kegiatan selanjutnya sehingga mereka tidak keluar dari jalur yang sudah ditetapkan.

Kecerdasan intelektual dalam Paskibraka juga dibekalkan kepada calon anggota Paskibraka melalui pola pembinaan dan pengasuhan saat latihan rutin di Lapangan Upakarti setiap hari Minggu, termasuk juga saat memasuki pemusatan latihan yang dikarantina.

Kecerdasan emosional dalam Paskibraka selalu diolah dalam setiap kegiatan, karena dalam bentuk kelompok tentunya dihadapkan pada pemasalahan baik permasalahan antar individu maupun kelompok. Di sinilah emosional calon anggota Paskibraka diuji dan dilatih sehingga mereka dapat memahami dan menghargai perbedaan yang ada dalam kelompoknya untuk dapat nantinya mencapai tujuan bersama.

Berikutnya adalah kemampuan atau kecerdasan dalam hidup mandiri dan 
kedisiplinan. Kemampuan atau kecerdasan ini sangat terkait sekali dengan kepribadian calon anggota Paskibraka yang telah diajarkan materi-materi yang diajarkan dalam latihan rutin oleh senior-senior PPI Kabupaten Bandung hingga nanti saat masuk ke dalam karantina. Terlebih dalam PBB tidak boleh terdapat kesalahan seorang individu, karena dapat merusak kekompakan kelompoknya. Materi-materi tersebut sangatlah berguna dan harus dipelajari sebagai bekal awal bela negara karena ketika negara kita dalam keadaan darurat maka anggota Paskibraka atau generasi muda kita telah siap dengan kemampuan yang ada untuk mengahadapi kesulitan dan untuk bertahan hidup.

Pembinaan dan pengasuhan oleh para staf Dispora dan PPI Kabupaten Bandung dalam memberikan santiaji dan materi yang diajarkan itu karena mereka akan mengaplikasikannya dalam karantina penggemblengan di Pusdiklat Paskhasau selama 12 hari, dimana calon anggota harus belajar dan berlatih secara simultan dan sangat menguras energi. Diharapkan dengan bekal awal saat pola bimbingan dan pengasuhan dapat bermanfaat bagi calon anggota Paskibraka dalam mengikuti pumusalatan latihan menjelang Upacara Pengibaran Bendera Merah Putih pada tanggal 17 Agustus.

Hal ini berarti peranan Paskibraka dalam membekali kemampuan awal bela negara secara samapta dan mental cukup besar dan terprogram dengan baik ini terlihat dari profil anggotanya yang senantiasa memelihara kesehatan jiwa dan raga, ulet dan pantang menyerah dalam menghadapi tantangan, terus membina kemampuan jasmani dan rohani serta memiliki kemampuan dasar bela negara dalam bentuk ketrampilan.. Ini juga sesuai dengan nilai bela negara yang dirumuskan dalam Permenhan No 32 Tahun 2016 yaitu memiliki kemampuan awal bela negara (kesiapan fisik dan mental).

\section{Komitmen Pemuda PPI Terhadap Bela Negara}

Menurut Meyer dan Allen dalam Soekidjan (2009:12), komitmen berarti penerimaan yang kuat individu terhadap tujuan dan nilai-nilai organisasi, dan individu berupaya serta berkarya dan memiliki hasrat yang kuat untuk tetap bertahan di organisasi tersebut.

Pendidikan yang mengajarkan tentang rasa cinta tanah air dan wawasan kebangsaan mutlak diperlukan dalam pluralisme bangsa kita, diharapkan dengan pendidikan ini, kita akan semakin kuat sebagai bangsa. Sebagai seseorang yang telah mendapatkan gemblengan berupa pendidikan dan latihan selama menjadi calon Paskibraka, para anggota Purna Paskibraka Indonesia Kabupaten Bandung menyatakan komitmennya yaituingin berbuat sesuatu untuk Indonesia dengan caranya masing-masing. Berkaca dari kondisi negara yang sedang mengalami berbagai macam problematika dalam berbagai sektor seperti sektor ideologi, politik, ekonomi, sosial-budaya, dan pertahanan keamanan, para anggota Purna Paskibraka Indonesia Kabupaten Bandung menyatakan bahwa mereka ingin berbuat sesuatu untuk memajukan bangsa Indonesia.

Komitmen pertama adalah tumbuhnya rasa kepedulian terhadap kondisi bangsa dan negara, sehingga tidak apatis terhadap kondisi negara, minimal pada lingkungan tempat tinggalnya. Posisi alumni PPI Kabupaten Bandung yang tersebar dalam berbagi profesi, baik yang masih berstatus pelajar atau mahasiswa maupun pekerja profesional harus memiliki sikap dan sifat 
tanggap terhadapa dinamika lingkungannya. Hal ini menunjukkan bahwa para anggota Purna Paskibraka Kabupaten Bandung telah memiliki pemahaman dan terdoktrin dengan baik dalam hal nasionalisme dan patriotisme, sehingga mereka memiliki komitmen terhadap bela negara yang ditunjukkan dengan ingin berbuat sesuatu kepada bangsa Indonesia.

Komitmen lainnya berupa kesiapan secara pribadi dari tiap anggota PPI jika diminta untuk turun dalam pembelaan negara secara fisik, yaitu membela negara dari agresi militer maupun non militer. Kesiapan dan komitmen untuk bela negara tidak hanya ditunjukkan lewat kegiatan saja, namun juga kesiapan untuk mengangkat senjata apabila memang diperlukan.

\section{SIMPULAN}

Berdasar penjelasan tersebut di atas dapat ditarik simpulan sebagai berikut.

Pertama, internalisasi nilai-nilai bela negara dapat dilakukan melalui dua kegiatan, yaitu melalui kegiatan Tata Upacara Bendera dan Peraturan Baris Berbaris. Pada setiap kegiatan upacara dan latihan baris-berbaris memiliki kekhasan materi atau ciri khusus tertentu yang ditunjukkan lewat gerakan dan materi-materi yang diajarkan selama proses pendidikan dan pelatihan saat penggemblengan mulai dari Capaska, dilantik dan dikukuhkan menjadi anggota Paskibraka Kabupaten Bandung hingga menjadi purna tugas sebagai anggota PPI (Purna Paskibraka Indonesia).

Kedua, pada kegiatan upacara bendera, penanaman nilai-nilai kebangsaan melalui upacara bendera, terutama pada saat momen sakral berupa upacara peringatan hari kemerdekaan Republik Indonesia dan Peringatan Hari Besar Nasional. Nilai-nilai ini didapatkan ketika mereka menjalani pendidikan dan pelatihan serta pada prosesi pelaksanaan upacara bendera berlangsung. Rangkaian pendidikan dan pelatihan hingga prosesi pelaksanaan upacara bendera yang terdiri dari pelatihan fisik dan mental memberikan pengaruh bagi karakter mereka. Pelatihan samapta yang terukur, bertahap, bertingkat dan berlanjut akan membentuk kekuatan fisik yang semakin kuat dan trengginas, sedangkan pelatihan mental membentuk karakter Paskibraka menjadi lebih tanggap, tangguh dan percaya diri dalam melaksanakan tugasnya.

Ketiga, pembinaan PPI Kabupaten Bandung Paskibraka berperan aktif dalam penanaman nilai-nilai bela negara terhadap anggota calon Paskibraka selama proses penggemblengan yang sesuai Permenhan RI No. 32 Tahun 2016 dengan lima parameternya yaitu (1). Menanamkan rasa cinta kepada tanah airnya, (2). Menumbuhkan kesadaran berbangsa dan bernegara melalui wawasan kebangsaan, (3). Menanamkan kesadaran bahwa Pancasila sebagai ideologi negara, (4). Menumbuhkan sikap rela berkorban untuk bangsa dan negara, (5). Memiliki kemampuan pendahuluan pendidikan bela negara (kesiapan dari segi fisik dan mental).

Keempat, hasil interpretasi dari wawancara secara berkesinambungan, observasi lapangan secara kontinu, literatur dokumentasi dan pustaka menunjukkan bahwa setiap narasumber menyatakan bahwa ke-lima indikator pembentuk ketahanan pribadi ini tercakup dalam kegiatan Paskibraka, dimana Paskibraka merupakan salah satu wadah yang teruji baik dalam proses peningkatan kesadaran nilai bela negara sesuai Permendagri Nomor 38 Tahun 2011.

Kelima, dari hasil penelitian yang dilakukan kontribusi internalisasi nilai- 
nilai bela negara mewujudkan ketahanan pribadi selama proses pendidikan dan latihan intensif anggota paskibraka ditunjukkan dengan beberapa indikator yang membentuk karakter pribadi anggota Paskibraka dalam mendukung kegiatan bela negara, yaitu memiliki kemantapan spiritual, kemantapan sosial dan mental, sikap pantang menyerah dan percaya diri, berjiwa patriotik, danmemiliki ketrampilan dalam protokoler

\section{DAFTAR PUSTAKA}

Abdullah, I., 2010., Berpihak Pada Manusia: Paradigma Nasional Pembangunan Indonesia Baru., Yogyakarta: TICI Publications bekerjasama dengan PustakaPelajar.

Armawi, A. 2006. "Refleksi Filosofis terhadap Reformasi Akhlak dan Masa Depan Bangsa".Jurnal Ketahanan Nasional Nomor XI (1) Volume April 2006.

Basrie, C., 1994., Pemantapan Pembangunan Melalui Pendekatan Ketahanan Nasional. Kumpulan Karangan dalam Rangka Pengkajian Ketahanan Nasional, Jakarta : UI dan Dephankam (Kerjasama). ,1998., Bela Negara: Implementasi dan Pengembangannya (Penjabaran Pasal 30 UUD 1945), Jakarta: UI Press.

Buasan, B., 2013, Perilaku Nasionalistik Masa Kini dan Ketahanan Nasional, Yogyakarta : Mata Bangsa.

Darmono, B. 2010. Konsep dan Sistem Keamanan Nasional Indonesia. Jurnal Ketahanan Nasional Nomor XV (1), Volume April 2010.

Djono, 2016. “Internalisasi Nilai dalam Pembelajaran", Juni, <https://www.lyceum. id/internalisasi-nilai-pembelajaran/> (diakses 11 Januari 2018).
Kaelan, H., 2012, Metode Penelitian Kualitatif Interdisipliner, Yogyakarta : Paradigma.

Mardalis., 1990, Metode Penelitian: Suatu Pendekatan Proposal, Jakarta: Bumi Aksara.

Martodirjo, H.S. 2008. "Implementasi Pancasila dalam Menumbuh kembangkan Wawasan Kebangsaan". Jurnal Ketahanan Nasional, Nomor XIII(2), Volume April 2008.

Mu'in, F., 2016, Pendidikan karakter, Konstruksi Teoretik dan Praktik, Yogyakarta: Ar-Ruzz Media.

Patton, M.Q., 2009, Metode Evaluasi Kualitatif, Yogyakarta: Pustaka Pelajar.

Perwita, AA Banyu., 2006, "Hakikat, Prinsip dan Tujuan HamKamNeg", dalam Mencari Format Komprehensif Sistem Pertahanan dan Keamanan Negara, Diedit oleh, Prihatono, Hari T dan Anak Agung Banyu Perwita, Jakarta: Pro Patria Institute, hal 27-43.

Setiawan, M Budi., 2009., Mozaik Gerakan Pemuda Kontemporer., Jakarta:

Kementrian Negara Pemuda dan Olahraga RI Deputi Bidang Pengembangan Kepemimpinan Pemuda.

Soekidjan, S., 2009., Komitmen Organisasi Apakah Sudah Dalam Diri Anda? Jakarta: Rineka Cipta.

Suryaningrat, W., 2018. "Pembinaan Kegiatan Pemuda Purna Paskibraka Indonesia (PPI) dalam Penanaman Nilai-Nilai Bela Negara dan Implikasinya Terhadap Ketahanan Pribadi (Studi PPI Kabupaten Bandung)". Tesis. Yogyakarta : Sekolah Pascasarjana Universitas Gadjah Mada.

Wahana, H.D., 2015, "Pengaruh Nilai-nilai Budaya Generasi Millennial dan Budaya Sekolah tehadap ketahanan Individu", 
Widodo Suryaningrat, Armaidy Armawi, Djoko Soerjo -- Internalisasi Bela Negara Dalam Pembinaan Kegiatan Pemuda Purna Paskibraka Kabupaten Bandung Untuk Pembentukan Ketahanan Pribadi

Jurnal Ketahanan Nasional, (internet), April, 21 (1) hal 14-22. <https://jurnal. ugm.ac.id/jkn>

\section{Perundang-undangan}

Undang-Undang Nomor 3 Tahun 2002 tentang Sistem Pertahanan Negara

Undang-Undang Nomor 40 Tahun 2009 tentang Kepemudaan

Peraturan Menteri Dalam Negeri (Permendagri) No. 38 Tahun 2011 tentang
Pedoman Peningkatan Kesadaran Bela Negara di Daerah.

Peraturan Menteri Pemuda dan Olahraga Republik Indonesia No. 0065 Tahun 2015 Tentang Penyelenggaraan Kegiatan Pasukan Pengibar Bendera Pusaka (Paskibraka).

Peraturan Menteri Pertahanan Nomor 32 Tahun 2016 tentang Pedoman Pembinaan Kesadaran Bela Negara. 